\title{
The shallow-water fish assemblage of Isla del Coco National Park, Costa Rica: structure and patterns in an isolated, predator-dominated ecosystem
}

\author{
Alan M. Friedlander ${ }^{1}$, Brian J. Zgliczynski², Enric Ballesteros ${ }^{3}$, Octavio Aburto-Oropeza ${ }^{2}$, \\ Allan Bolaños ${ }^{4} \&$ Enric Sala ${ }^{3,5}$ \\ 1. US Geological Survey, Hawaii Cooperative Fishery Research Unit, University of Hawaii, 2540 Campus Road, \\ Honolulu, Hawaii 96822 USA; alan.friedlander@hawaii.edu \\ 2. Center for Marine Biodiversity and Conservation, Scripps Institution of Oceanography, University of California, San \\ Diego, 9500 Gilman Drive, San Diego, California 92093-0202, USA; bzgliczy@ucsd.edu, maburto@ucsd.edu, \\ 3. Centre d'Estudis Avançats de Blanes, CSIC, 17300 Blanes, Spain; kike@ceab.csic.es \\ 4. PRETOMA, Apdo. 1203-1100 Tibás, San José, Costa Rica, tortugamop@yahoo.com \\ 5. National Geographic Society, Washington DC 20036 USA; esala@ngs.org
}

\section{Received 05-III-2012. Corrected 20-VII-2012. Accepted 24-IX-2012.}

\begin{abstract}
Fishes at Isla del Coco National Park, Costa Rica, were surveyed as part of a larger scientific expedition to the area in September 2009. The average total biomass of nearshore fishes was 7.8 tonnes per ha, among the largest observed in the tropics, with apex predators such as sharks, jacks, and groupers accounting for nearly $40 \%$ of the total biomass. The abundance of reef and pelagic sharks, particularly large aggregations of threatened species such as the scalloped hammerhead shark (up to 42 hammerheads ha $^{-1}$ ) and large schools of jacks and snappers show the capacity for high biomass in unfished ecosystems in the Eastern Tropical Pacific. However, the abundance of hammerhead and reef whitetip sharks appears to have been declining since the late 1990s, and likely causes may include increasing fishing pressure on sharks in the region and illegal fishing inside the Park. One Galapagos shark tagged on September 20, 2009 in the Isla del Coco National Park moved 255km southeast towards Malpelo Island in Colombia, when it stopped transmitting. These results contribute to the evidence that sharks conduct large-scale movements between marine protected areas (Isla del Coco, Malpelo, Galápagos) in the Eastern tropical Pacific and emphasize the need for regional-scale management. More than half of the species and $90 \%$ of the individuals observed were endemic to the tropical eastern Pacific. These high biomass and endemicity values highlight the uniqueness of the fish assemblage at Isla del Coco and its importance as a global biodiversity hotspot. Citation: Friedlander, A., B.J. Zgliczynski, E. Ballesteros, O. Aburto-Oropeza, A. Bolaños \& E. Sala. 2012. The shallow-water fish assemblage of Isla del Coco National Park, Costa Rica: structure and patterns in an isolated, predator-dominated ecosystem. Rev. Biol. Trop. 60 (Suppl. 3): 321-338. Epub 2012 Dec 01.
\end{abstract}

Key words: apex predators, Tropical Eastern Pacific, Isla del Coco, shark fishing, marine protected area, endemism, biodiversity hotspot, Costa Rica.

The health of marine ecosystems worldwide is in decline and under ever increasing threats from multiple anthropogenic stressors (e.g., overfishing, pollution, habitat loss, and climate change). Because of the extent of the global human footprint on these ecosystems (Halpern et al. 2008, Mora et al. 2011), our understanding of what is natural in the marine environment is becoming increasingly compromised by the absence of locations that lack substantial human impacts. Large, remote protected areas give us some indication of how marine ecosystems function in the absence of local human influences (Friedlander \& DeMartini 2002, Sandin et al. 2008, Knowlton \& Jackson 2008) and from these locations it is clear that many marine ecosystems were once dominated by large predators (Jackson et al. 2001, Estes et al. 2011).

Isla del Coco, Costa Rica, is known worldwide for its aggregations of sharks and other mega-fauna (Bakus 1975, Garrison 2005). It 
was designated a National Park by Costa Rica in 1978, and in 2001 the park's limits were extended to currently include $1997 \mathrm{~km}^{2}$ of protected marine ecosystem $(22.2 \mathrm{~km}$ radius from the island). Within the park boundaries, extraction of marine resources, as well as all other commercial, industrial, and agricultural activities are banned (Executive Decree $N^{\circ} 29834-$ MINAE). Because of its global significance, Isla del Coco National Park was declared a UNESCO World Heritage site in 1997 and a Ramsar wetland of international importance in 1998 (Cortés 2008).

Isla del Coco is located in the Eastern Tropical Pacific (ETP) Biogeographic Region, which is delimited by the Gulf of California southward to the northern boundary of Peru and includes five oceanic islands and archipelagos (Hastings 2000; see Figure 1). The diversity of the nearshore fauna found in the ETP is relatively low compared to other locations in the Indo-Pacific due to the regions geographic isolation and complex oceanographic conditions.
As a result of these conditions, the ETP is considered the most isolated marine biogeographic region in the world with the highest endemism of nearshore fishes found anywhere (Hastings and Robertson 2001, Robertson et al. 2004). Of the 1285 shallow-water $(<100 \mathrm{~m})$ fishes in the ETP, $79 \%$ are endemic to the region (Robertson \& Allen 2008). Within the ETP, there are three major recognized biogeographic provinces: 1) Cortez (Gulf of California and lower Pacific Baja), 2) Panamic (southward along the continental margin to Peru), and 3) the five oceanic islands/archipelagos including Galapagos, Isla del Coco and Malpelo (Robertson \& Cramer 2009). Currently there are 270 nearshore species reported from Isla del Coco, including 27 species endemic only to the island $(10 \%$ of the fauna), plus 20 insular endemics known only from Isla del Coco and other offshore islands in the ETP (Bussing \& López 2005, Garrison 2005).

National Geographic Society, in partnership with the Universidad de Costa Rica and

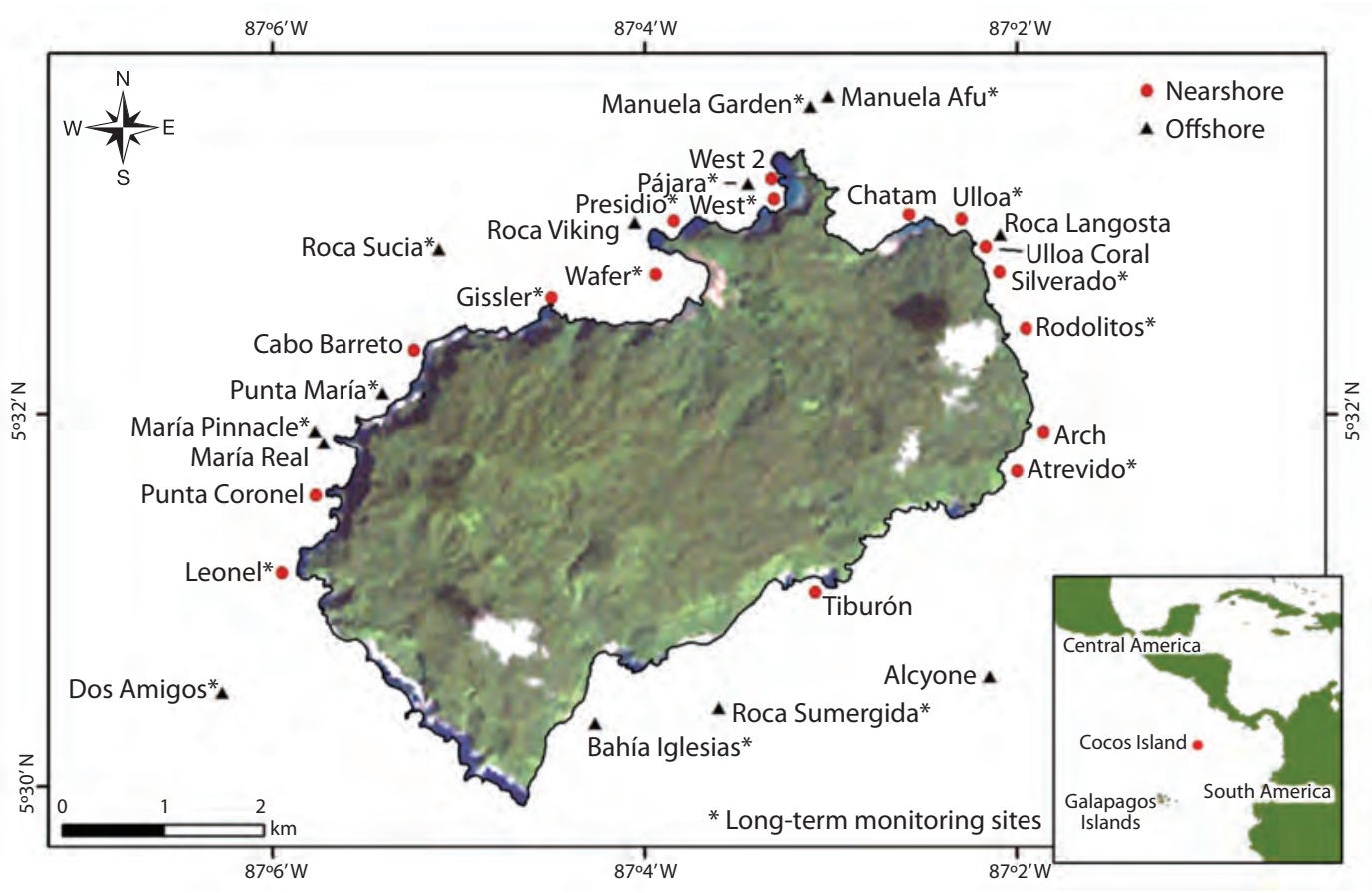

Fig. 1. Sampling locations around Isla del Coco. Nearshore locations are denoted by circles and offshore islets and pinnacles are denoted by triangles. * Denotes sites evaluated by Edgar et al. 2011. 
local conservation organizations conducted a scientific expedition to Isla del Coco and Las Gemelas seamounts, Costa Rica, from September 9 to 24, 2009. The goals of the expedition were to: 1) describe the biogeography and endemism of the nearshore fish assemblage; 2) measure the abundance, size, and biomass of reef and pelagic fishes, including sharks at Isla del Coco National Park; 3) conduct a preliminary assessment of the migratory movements of sharks; and 4) explore and survey deep habitats in the National Park and the then unprotected Las Gemelas seamounts south of the Park (see Starr et al. 2012).

\section{MATERIALS AND METHODS}

Study site: Isla del Coco is located approximately $550 \mathrm{~km}$ southwest of Cabo Blanco, Costa Rica, and about $560 \mathrm{~km}$ northeast of the Galapagos at $5^{\circ} 32^{\prime}-5^{\circ} 34^{\prime} \mathrm{N}, 87^{\circ} 01^{\prime}-87^{\circ} 06^{\prime} \mathrm{W}$ (Fig. 1). It is the summit of a seamount on the Coco Volcanic Cordillera (also known as Cocos Ridge) that was formed ca. 2 m.y. ago along the Galapagos Hot Spot (Castillo et al. 1988). The steep-sided and well vegetated island lies within the Inter-Tropical Convergence Zone and receives more than $7 \mathrm{~m}$ of rainfall annually (Alfaro 2008). The island is $4.4 \times 7.6 \mathrm{~km}$ with a perimeter of $23.3 \mathrm{~km}$ and an area of $23.2 \mathrm{~km}^{2}$ (Cortés 2008)

Survey stations were spaced around the island coinciding with previous surveys (Edgar et al. 2011) to contribute to the time-series of data for the island (Table 1). Additional stations were added to provide for more spatially comprehensive sampling and to target important "ecological hotspots" such as hammerhead cleaning stations, unique geographic features, and offshore islets. Sampling was stratified by depth consistent with strata established by Edgar et al. (2011) and by nearshore vs. offshore islets and pinnacles.

Visual surveys of the fish assemblage: To estimate the abundance and biomass of nearshore fishes, surveys were conducted by a team of paired divers. At each station, one diver tallied all fishes encountered within fixedlength $(25-\mathrm{m})$ belt transects whose widths differed depending on the direction of swim. Transect bearings were determined haphazardly along isobaths; two isobaths were sampled with belt transects (shallow $=5-10 \mathrm{~m}$, deep $=$ 11-18m). These depth strata were consistent with those established by Edgar et al. (2011). Large-bodied vagile fishes $\geq 20 \mathrm{~cm}$ total length (TL) were tallied within an 4-m wide strip surveyed on an initial "swim-out" as the transect line was laid, focusing observations ahead in a $5 \mathrm{~m}$ long moving window. Small-bodied, less vagile and more site-attached fish $<20 \mathrm{~cm}$ TL were tallied within a 2-m wide strip surveyed on the return swim back along the laid transect line. Fishes were recorded by species or lowest recognizable taxon. Nomenclature followed Garrison (2005). Tallies were binned by 5-cm TL class.

The survey methodology was designed to minimize bias associated with in situ underwater visual censuses (Mapstone \& Ayling 1998). Constraints on the focal window size and survey duration for the swim-out limited problems of over-counting large-bodied, vagile species such as sharks. Use of two transect areas (4m vs. $2 \mathrm{~m}$ lanes) compensates for some of the size-specific differences in density, namely that larger-bodied fish are typically less abundant than their smaller-bodied counterparts, addressing some concerns of differing patterns of variance across size classes (DeMartini et al. 2008, Friedlander et al. 2010).

The biomass of individual fishes was estimated using the allometric length-weight conversion: $\mathrm{W}=\mathrm{a} \mathrm{TL}{ }^{\mathrm{b}}$, where parameters $\mathrm{a}$ and $\mathrm{b}$ are species-specific constants, TL is total length in $\mathrm{cm}$, and $\mathrm{W}$ is weight in grams. Length-weight fitting parameters were obtained from FishBase

Froese \& Pauly (2011) and other published sources (Letourneur 1998, Kulbicki et al. 2005) with the cross-product of individual weights and numerical densities used to estimate biomass by species. Numerical density (abundance) was expressed as number of individuals per $100 \mathrm{~m}^{2}$ and biomass was expressed as tonnes (t) per hectare (ha). Fishes were 
TABLE 1

Sampling location conducted around Isla del Coco

\begin{tabular}{|c|c|c|c|c|c|c|c|}
\hline \multirow[b]{2}{*}{ Station } & \multirow[b]{2}{*}{ Lat. } & \multirow[b]{2}{*}{ Long. } & \multirow{2}{*}{$\begin{array}{l}\text { Offshore islets and } \\
\text { pinnacles }\end{array}$} & \multicolumn{2}{|c|}{ Belt } & \multicolumn{2}{|c|}{$\mathrm{SPC}$} \\
\hline & & & & $\begin{array}{c}\text { Deep } \\
(11-18 \mathrm{~m})\end{array}$ & $\begin{array}{l}\text { Shallow } \\
(5-10 \mathrm{~m})\end{array}$ & $\begin{array}{c}\text { Deep } \\
(11-33 \mathrm{~m})\end{array}$ & $\begin{array}{l}\text { Shallow } \\
(5-10 \mathrm{~m})\end{array}$ \\
\hline Alcyone & 5.5100 & -87.0325 & $X$ & & & 75 & \\
\hline Arch & 5.5319 & -87.0276 & & 2 & 2 & 15 & 15 \\
\hline Cabo Atrevido* & 5.5284 & -87.0300 & & 2 & 2 & 15 & 15 \\
\hline Bahía Iglesias* & 5.5058 & -87.0678 & $\mathrm{X}$ & 2 & 2 & 15 & 15 \\
\hline Cabo Barreto & 5.5387 & -87.0835 & & 2 & 2 & 15 & 15 \\
\hline Bahia Chatham & 5.5513 & -87.0397 & & 2 & 2 & 15 & 15 \\
\hline Roca Sucia* & 5.5482 & -87.0817 & $\mathrm{X}$ & 2 & 2 & 95 & 15 \\
\hline Dos Amigos* & 5.5086 & -87.1012 & $\mathrm{X}$ & 2 & & 15 & \\
\hline Punta Gissler* & 5.5434 & -87.0718 & & 2 & 2 & 15 & 15 \\
\hline Punta Leonel* & 5.5193 & -87.0958 & & 4 & & 15 & 15 \\
\hline Manuelita Afuera* & 5.5610 & -87.0485 & X & 4 & 2 & 135 & 15 \\
\hline Isla Manuelita* & 5.5619 & -87.0469 & $\mathrm{X}$ & 2 & 2 & 15 & 15 \\
\hline Maria Pinnacle* & 5.5319 & -87.0929 & $X$ & & & 30 & \\
\hline Punta Maria* & 5.5354 & -87.0868 & & 2 & 2 & 15 & 15 \\
\hline Punta Maria Real & 5.5310 & -87.0914 & & 2 & 2 & 15 & 15 \\
\hline Isla Pájara Sur* & 5.5541 & -87.0541 & $X$ & 2 & 2 & 15 & 15 \\
\hline Punta Presidio* & 5.5499 & -87.0604 & & 2 & 2 & 26 & 19 \\
\hline Punta Coronel & 5.5260 & -87.0922 & & 2 & 2 & 15 & 15 \\
\hline Roca Langosta & 5.5495 & -87.0315 & $X$ & & & 12 & 3 \\
\hline Rodolitos* & 5.5411 & -87.0292 & & 2 & 2 & 15 & 15 \\
\hline Silverado Norte* & 5.5461 & -87.0320 & & 2 & 2 & 15 & 15 \\
\hline Roca Sumergida* & 5.5072 & -87.0567 & $X$ & 2 & & 15 & \\
\hline Bahía Inútil* & 5.5176 & -87.0481 & & 2 & 2 & 15 & 15 \\
\hline Punta Ulloa* & 5.5509 & -87.0349 & & 2 & 2 & 15 & 15 \\
\hline Ulloa Coral & 5.5487 & -87.0340 & & 2 & 2 & 15 & 15 \\
\hline Roca Viking & 5.5506 & -87.0642 & $X$ & 2 & 2 & 30 & 15 \\
\hline Bahía Wafer* & 5.5460 & -87.0623 & & 2 & 2 & 15 & 15 \\
\hline Bahia Western* & 5.5523 & -87.0509 & & & & 7 & 8 \\
\hline Bahia Western 2 & 5.5537 & -87.0514 & & 2 & 2 & 15 & 15 \\
\hline Total & & & & 54 & 44 & 459 & 356 \\
\hline
\end{tabular}

Datum $=$ WGS 84. SPC $=$ stationary point counts. * Denotes sites evaluated by Edgar et al. (2011).

categorized into four functional trophic groups: herbivores (primary consumers and detritivores); planktivores (secondary consumers); lower-level carnivores (benthic carnivores); and apex predators (Friedlander et al. 2010).

Visual surveys of predators and pelagic species: Owing to the difficulty in counting highly mobile apex predators and pelagic species, we implemented a modified stationary point count (SPC) method (Thresher \& Gunn 1986), at the same sites of the belt transects and at additional sites where large pelagic fishes aggregate to feed or be cleaned. Sampling was stratified by depth (shallow $=5-10 \mathrm{~m}$, deep $=$ $11-33 \mathrm{~m})$. A diver arrived at the site, selected a haphazard location within the transect area or cleaning station, and conducted an instantaneous count of all apex predators and other large resource species within a $10 \mathrm{~m}$ radius 
cylinder every 2 minutes for 30 minutes ( $\mathrm{n}=15$ per strata per site). An index of relative dominance (IRD) for each fish taxon was created by multiplying the percent frequency of occurrence of the species at each station-depth strata combination by the relative percent biomass of that species (Friedlander et al. 2003).

Shark satellite tagging: To study the regional migratory movements of sharks, we tagged a Galapagos shark (Carcharinus galapagensis) using a PAT-MK3 pop-up satellite tag manufactured by Wildlife Computers. The shark was caught near Roca Sucia with a barbless hook, the tag was implanted just ventral of the dorsal fin, and the shark was released within minutes. The tag was programmed to pop up at the end of March 2009.

Shark observations from dive-master logs: Data for several larger marine species were collected over a 15 year period (1991 to 2007) by dive-masters from the Undersea Hunter diving company at 27 sites around Isla del Coco (Sibaja-Cordero 2008). The number of individuals for each species per dive was calculated from these data and examined over the time series. Data from 1991 and 1992 were incomplete and excluded from the analyses.

Data analysis: Fish assemblage characteristics (species richness, numerical abundance, and biomass) were compared between shallow and deep depth strata using a Student's t test. Numerical abundance and biomass were $\ln (x+1)$ transformed prior to statistical analysis to conform to the assumptions of parametric statistics (Zar 1999). Normality was tested using a Shapiro-Wilk W test $(\mathrm{p}<0.05)$ while a Bartlett's test $(\mathrm{p}<0.05)$ was used to examine homogeneity of variance.

Comparisons of total biomass and biomass of each trophic group between shallow and deep depth strata from belt transects were conducted using Wilcoxon Rank Sum tests. Comparisons of total fish biomass between offshore islets and nearshore locations from SPCs were also tested using a Wilcoxon Rank
Sum test. Non-metric multi-dimensional scaling (nMDS) analysis, coupled with an analysis of similarities (ANOSIM) test, was conducted using PRIMER v. 5 (Clarke and Gorley 2001) to examine differences in fish assemblages between location from shore (nearshore vs. offshore) and depth strata. The data matrix consisted of fish biomass in $\mathrm{g} 100 \mathrm{~m}^{-2}$ by species for each location and depth. A Bray-Curtis similarity matrix was created from the fish biomass matrix prior to conducting the nMDS. ANOSIM is a permutation-based hypothesis testing analysis of similarities (ANOSIM in PRIMER 5.0 [Primer-E Ltd., Plymouth, UK]) that generates an $\mathrm{R}$ statistic that is on a scale from 0 or negative value (identical assemblages) to 1 (completely dissimilar assemblages). The resulting $\mathrm{P}$ value indicates the probability that the two assemblages come from a similar distribution (Clarke and Warwick 2001). Pairwise ANOSIM R statistics represent comparisons that are well separated $(R>0.75)$, overlapping but clearly different $(\mathrm{R}>0.5)$, or barely separable at all $(\mathrm{R}<0.25)$. ANOSIM was used to compare assemblages between nearshore and offshore locations and depth strata. Time series data of shark observations were smoothed using a weighted regression (LOESS), with the dependent variable $(\ln$ [number of sharks per dive]) smoothed as a function of the independent variables (year) with a polynomial smoother of degree 1 and a nearest neighbor interval of 3 (Sigmaplot 11.0 2008).

\section{RESULTS}

Endemism and biogeography: More than $50 \%$ of the species and $91 \%$ of the individuals surveyed on belt transects at Isla del Coco are endemic to the ETP (Table 2). The vast majority of these species are common to the entire region, however five species ( $5.7 \%$ of the total) were endemic to Isla del Coco only, accounting for $3.7 \%$ of the total numerical abundance observed. An additional four species (4.6\% of the total) are known only from the oceanic islands of the ETP and accounted for $4.3 \%$ of the observed numerical abundance. 
TABLE 2

Biogeographical patterns of the fish assemblage at Isla del Coco

\begin{tabular}{lcccc}
\multicolumn{1}{c}{ Distribution } & Numerical density & \% Numerical density & Species richness & \% Species richness \\
ETP-ALL & $\mathbf{6 0 9 . 8}(\mathbf{2 8 2 . 2})$ & 91.3 & 44 & 50.58 \\
ETP & $556.4(258.4)$ & 83.31 & 35 & 40.23 \\
ETP-Oceanic & $28.6(78.5)$ & 4.28 & 4 & 4.60 \\
Isla del Coco & $24.8(38.5)$ & 3.71 & 5 & 5.75 \\
Indo-Pacific & $43.7(37.1)$ & 6.55 & 33 & 37.93 \\
Circumtropical & $14.4(22.6)$ & 2.15 & 10 & 11.49 \\
\hline
\end{tabular}

Numerical density - $\left(\right.$ No. $\left.100 \mathrm{~m}^{-2}\right)$. Values are means $( \pm \mathrm{SD})$.

Assemblage structure: A total of 108 species from 43 families were encountered during surveys ( $<30 \mathrm{~m}$ depth) at Isla de Coco. Quantitative belt transects conducted at 25 stations around the island (shallow $=44$ transects, deep $=54$ transects) revealed 87 species from 35 families. When averaged across all stations, species richness was $20.8(\mathrm{SD}=2.6)$ per transect, while the number of individuals was $670.0100 \mathrm{~m}^{-2}$ (268.6), and biomass was 7.6t ha-1 (7.6).

Species richness and numerical abundance were not significantly different between depth strata around the island ( $\mathrm{p}>0.05$ for both, Table $3)$. However, biomass was marginally significant $(\mathrm{p}=0.05)$ between depth strata, with biomass in the deep stratum $48 \%$ higher compared to the shallow stratum. Much of this difference was due to the presence of several shark species (mainly Carcharhinus albimarginatus and
Sphyrna lewini) in the deep stratum that were either absent on less common in the shallows. Species richness was similar between nearshore locations and offshore islets and pinnacles (Table 3, $\mathrm{p}=0.30$ ). The number of individuals and biomass were both significantly higher on offshore islets and pinnacles compared to nearshore locations $(\mathrm{p}<0.001$ and $\mathrm{p}=0.03$, respectively). Despite these differences, fish assemblage structure showed considerable overlap between nearshore and offshore locations (Fig. 2, Global $\mathrm{R}=0.08, \mathrm{p}=0.01$ ) and depth strata (Global $\mathrm{R}=0.04, \mathrm{p}=0.15$ ) based on nMDS of fish species biomass.

The black durgon (Melichthys niger) was the most abundant species by weight overall on belt transects, accounting for $17.2 \%$ of the total fish biomass and occurring at $78.7 \%$ of the station-depth strata combinations (Table 4). This was followed by the reef whitetip

TABLE 3

Comparison of fish assemblage characteristics from belt transects around Isla del Coco

\begin{tabular}{|c|c|c|c|c|}
\hline A. & Shallow & Deep & t-test & $\mathrm{p}$ \\
\hline Species richness & $20.88(2.55)$ & $20.81(2.79)$ & 0.10 & 0.92 \\
\hline Number of individuals (no. $100 \mathrm{~m}^{-2}$ ) & $611.5(236.1)$ & $721.5(289.2)$ & 1.43 & 0.16 \\
\hline Biomass $\left(\mathrm{t} \mathrm{ha}^{-1}\right)$ & $6.04(8.09)$ & $8.95(7.04)$ & 2.03 & 0.05 \\
\hline B. & Nearshore & Offshore & t-test & $\mathrm{p}$ \\
\hline Species richness & $20.53(2.74)$ & $21.34(2.50)$ & 1.04 & 0.30 \\
\hline Number of individuals (no. $100 \mathrm{~m}^{-2}$ ) & $567.7(219.9)$ & $834.7(262.8)$ & 3.60 & $\mathrm{p}<0.001$ \\
\hline $\operatorname{Biomass}\left(\mathrm{t} \mathrm{ha}^{-1}\right)$ & $6.16(6.40)$ & $9.88(8.95)$ & 2.24 & 0.03 \\
\hline
\end{tabular}

A. Shallow (5-10m) and deep (11-18m). B. Nearshore and offshore locations Statistical results of Student t-test (d.f.=45). Biomass $\ln (\mathrm{x}+1)$ transformed prior to statistical analysis. Values are means $( \pm \mathrm{SD})$. 


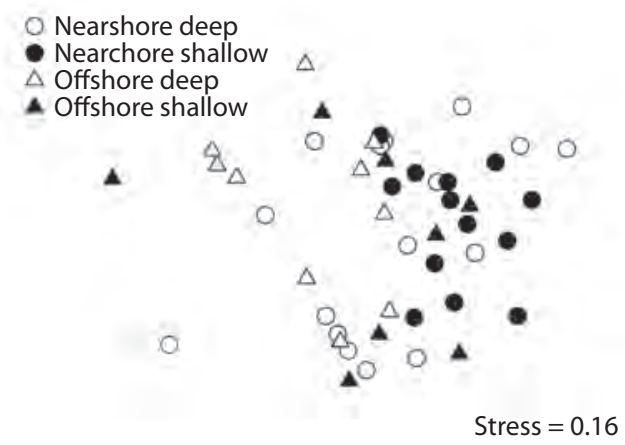

Fig. 2. Non-metric multidimensional scaling plot of fish assemblage structure, based on biomass $\left(\mathrm{g} 100 \mathrm{~m}^{-2}\right)$, between nearshore/offshore and depth strata.

shark (Triaenodon obesus), which accounted for $13.7 \%$ of the assemblage biomass and was present at $74 \%$ of the survey locations. Bluefin trevally (Caranx melampygus, 12.1\%) and the regionally endemic Pacific Creolefish (Paranthias colonus, 10.2\%) were next most important species by weight, followed by two additional shark species, the silvertip shark $(C$. albimarginatus, 6.0\%), and scalloped hammerhead (S. lewini, 4.8\%). The latter two shark species were only observed at $2.1 \%$ and $4.3 \%$ of the survey locations respectively, but their large size contributed disproportionately to the total assemblage biomass on belt transects.

The top five species based on numbers of individuals are all endemic to the ETP. The Cortez rainbow wrasse (Thalassoma lucasanum) was the most abundant species based on numbers, accounting for $47.1 \%$ of the numerical abundance within the assemblage and was present at every survey location (Table 4). This was followed by the yellowtail damselfish (Stegastes arcifrons, 20.6\%), Pacific creolefish (8.2\%), the blacktip cardinalfish (Apogon atradorsatus, 3.3\%), and Cocos wrasse (Halichoeres discolor, $2.9 \%$ ).

Trophic structure: Apex predators (primarily sharks and jacks) accounted for 39.3\% of the total biomass on belt transects, followed by planktivores $(30.4 \%)$, lower-level carnivores (15.6\%), and herbivores (14.6) (Fig. 3).

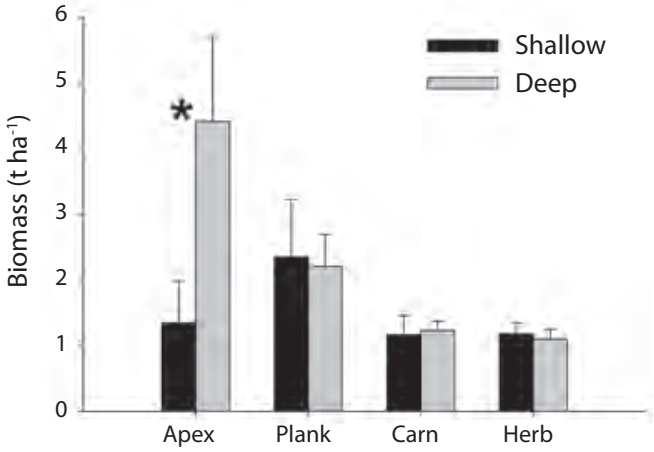

Fig. 3. Comparison of trophic biomass $\left(\mathrm{t} \mathrm{ha}^{-1}\right)$ between shallow $(5-10 \mathrm{~m})$ and deep (11-18m) depth strata at Isla del Coco. Error bars are standard error of the mean. * denotes significant difference between depth strata (see text for statistical results). Apex $=$ apex predators, Herb $=$ primary consumers and detritivores, Carn $=$ lower-level carnivores (benthic carnivores); and Plank = planktivores (secondary consumers).

Biomass of apex predators was significantly higher (Wilcoxon=2.72, $p=0.007$ ) in the deep stratum while biomass of all other trophic groups was indistinguishable between depth strata ( $>0.05$ for all, Table 5). Apex predator biomass was nearly two times higher on offshore islets and pinnacles compared to nearshore locations (Fig. 4, Wilcoxon=2.81,

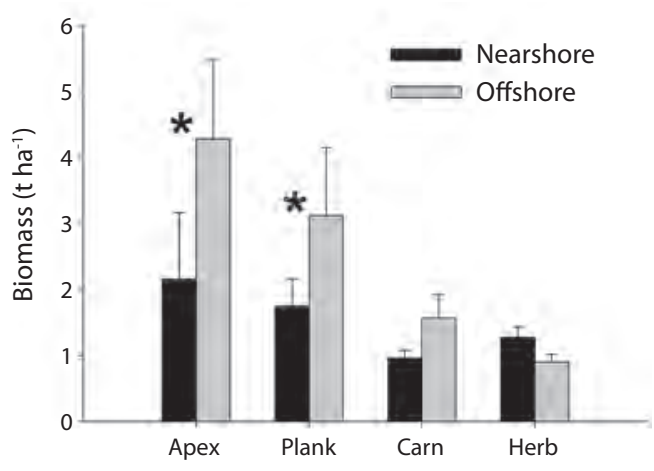

Fig. 4. Comparison of trophic biomass $\left(\mathrm{t} \mathrm{ha}^{-1}\right)$ between nearshore sites and offshore islets and pinnacles at Isla del Coco. Error bars are standard error of the mean. * denotes significant difference between depth strata (see text for statistical results). Apex $=$ apex predators, Herb $=$ primary consumers and detritivores, Carn $=$ lower-level carnivores (benthic carnivores); and Plank = planktivores (secondary consumers). 


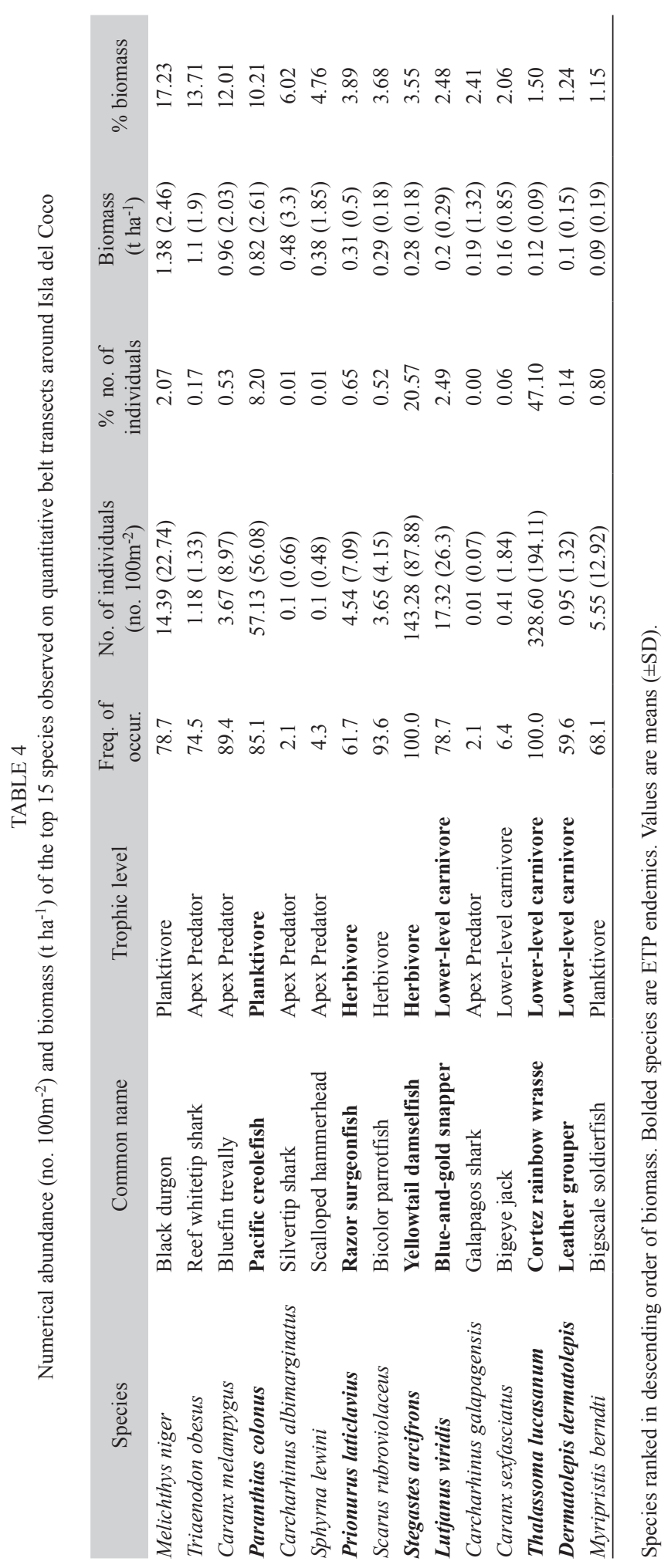




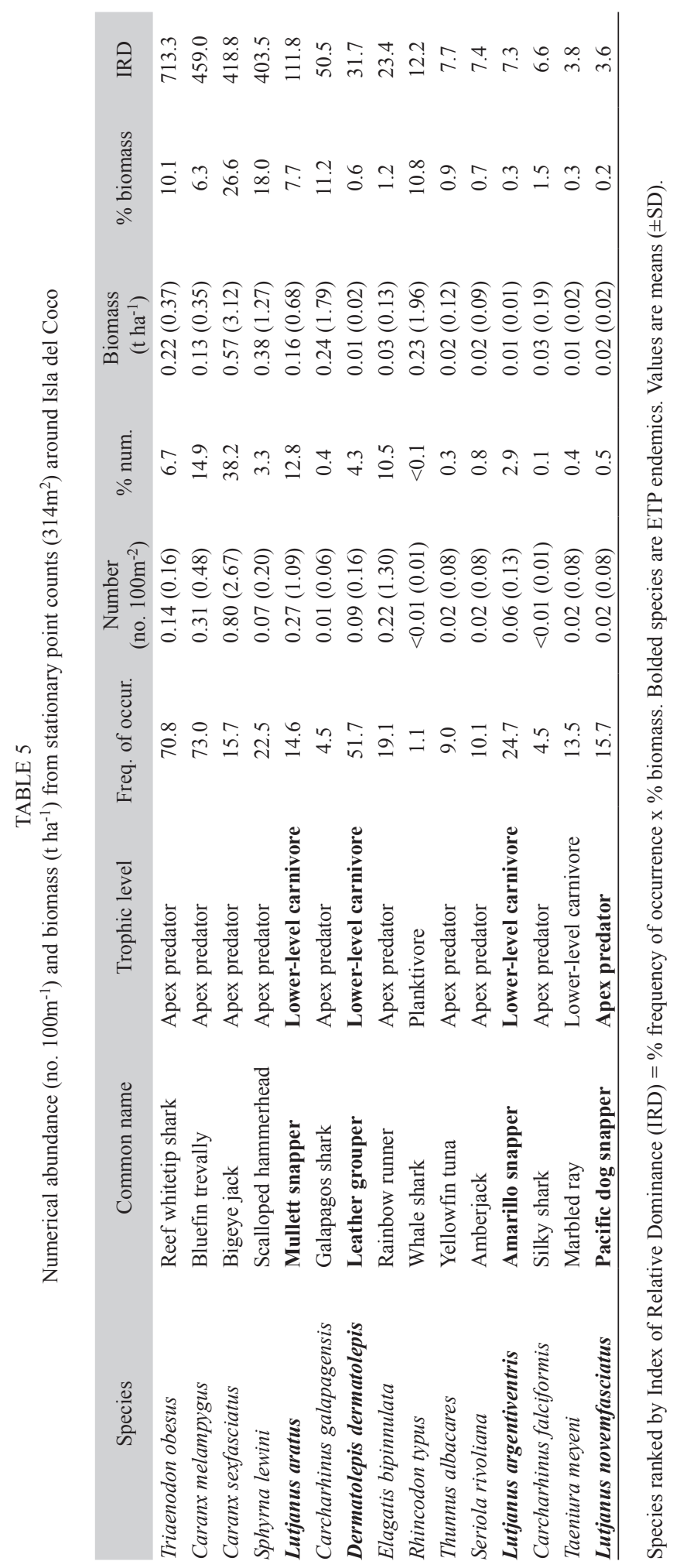


$\mathrm{p}=0.005$ ). Likewise, planktivore biomass was $80 \%$ higher offshore (Wilcoxon $=4.41, \mathrm{p}=0.03$ ). Biomass of other carnivores was $>60 \%$ higher offshore compared to nearshore, and although these differences were not significantly different the results are suggestive (Wilcoxon $=3.62$, $\mathrm{p}=0.06$ ). Herbivore biomass was $42 \%$ higher nearshore but these differences were not significant (Wilcoxon $=1.67, \mathrm{p}=0.20$ ).

Stationary point count data: A total of 32 species from 12 families were surveyed on 1085 SPCs (deep=725, shallow $=360$ ) around Isla del Coco. Reef whitetip sharks (Triaenodon obesus) had the highest index of relative dominance (IRD) among all species observed on SPCs (Table 5). They occurred at $71 \%$ of all station-depth strata combinations and ranked fifth by both weight $(10 \%)$ and numbers $(7 \%)$. Bluefin trevally ranked second in IRD, occurring in $73 \%$ of the surveys and ranking second in abundance and fifth in biomass. Although bigeye jacks (Caranx sexfasciatus) ranked first in total biomass $(27 \%$ of total), they were only present in $15 \%$ of the surveys and ranked third in IRD as a result. Ranked forth by IRD was the Scalloped hammerhead (S. lewini), which was observed in $23 \%$ of the station-depth strata combinations and was the second most abundant species by weight (18\%), but ranked seventh by numbers (3\%). Biomass from SPCs was significantly higher on offshore islets compared to nearshore locations (Wilcoxon=2.81, $\mathrm{p}=0.005$ ). Similarly, the abundance of the numerically dominant large resource species quantified on SPCs was also highest on the offshore islets (Fig. 5).

Shark movements: One $187 \mathrm{~cm}$ TL Galapagos shark (C. galapagensis) was tagged on September 20, 2009 at ca. 6:00 with a PATMK3 pop-up satellite tag. On October 10, the shark had moved $255 \mathrm{~km}$ southeast of Isla del Coco, towards Malpelo Island $\left(12.8 \mathrm{~km} \mathrm{day}^{-1}\right.$, Fig. 6). No additional detections were received after that date. Had the shark died and sunk to the bottom, the automatic pressure trigger would have released the tag, which floats, and returned to the surface. Had the tag been released involuntarily, it would have also floated back to the surface and transmitted back to the satellite. This result suggests that either the tag failed or the shark was fished. Efforts were made to tag other sharks, especially hammerheads, but these attempts were unsuccessful.

\section{Shark observations from dive-master}

logs: Data collected in the park by the Undersea Hunter dive masters since 1992 show that the abundance of hammerhead sharks and whitetip reef sharks have declined dramatically over time (Figs. 7a, b). Abundance of both hammerhead and whitetip reef sharks showed a peak in 1999 with the lowest values for both species observed in the most recent survey year (2007). These changes represent more than an 11 fold decline in hammerheads and a 2.8 fold decline whitetip reef sharks from peak abundance.

\section{DISCUSSION}

\section{Fish assemblage structure:}

The average total biomass of nearshore fishes at Isla del Coco National Park is among the largest recorded in the tropics worldwide. The abundance of reef and pelagic sharks, particularly large aggregations of threatened species such as the scalloped hammerhead shark (up to 42 hammerheads ha-1) and large schools of jacks and snappers makes Isla del Coco a place of unique global value and highlights the effectiveness of protection. More than half of the species and $90 \%$ of the individuals observed were endemic to the ETP. This high proportion of endemism highlights the uniqueness of the fish assemblage at Isla del Coco and its importance as a global biodiversity hotspot.

Due to the protection and enforcement in Isla del Coco National Park, the structural patterns of fishes observed reflect relatively natural ecological processes that are only modestly influenced by fishing but no other localized anthropogenic factors. The most striking feature of this assemblage is an 

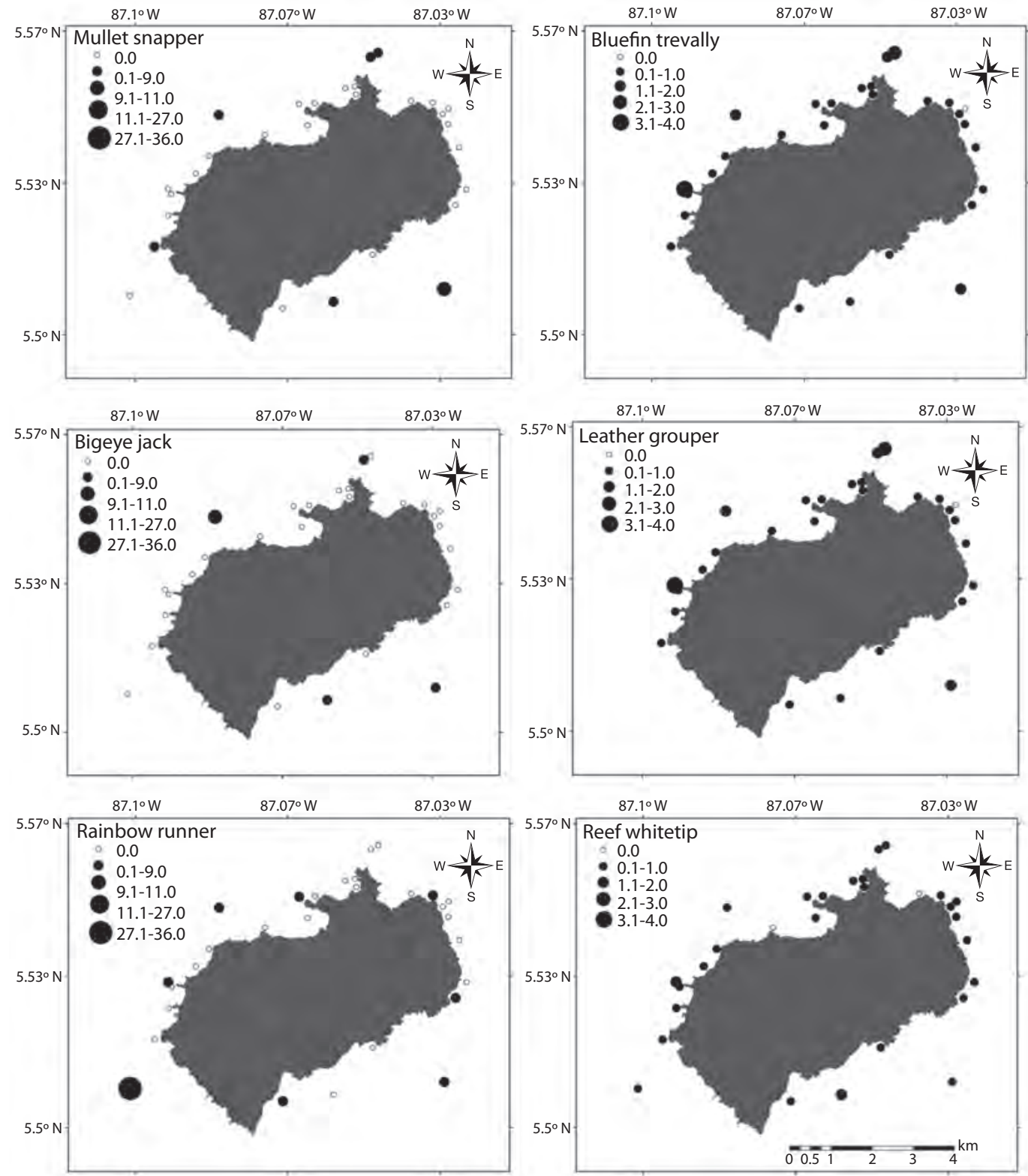

Fig. 5. Numerical abundance of important resource species observed on stationary point counts (number ha ${ }^{-1}$ ) at Isla del Coco. Bigeye jack = Caranx sexfasciatus, bluefin trevally = Caranx melampygus, Mullet snapper $=$ Lutjanus aratus, Rainbow runner $=$ Elagatis bipinnulata, Reef whitetip $=$ Triaenodon obesus, Leather grouper $=$ Dermatolepis dermatolepis . Note differences in scales between right and left panels. 


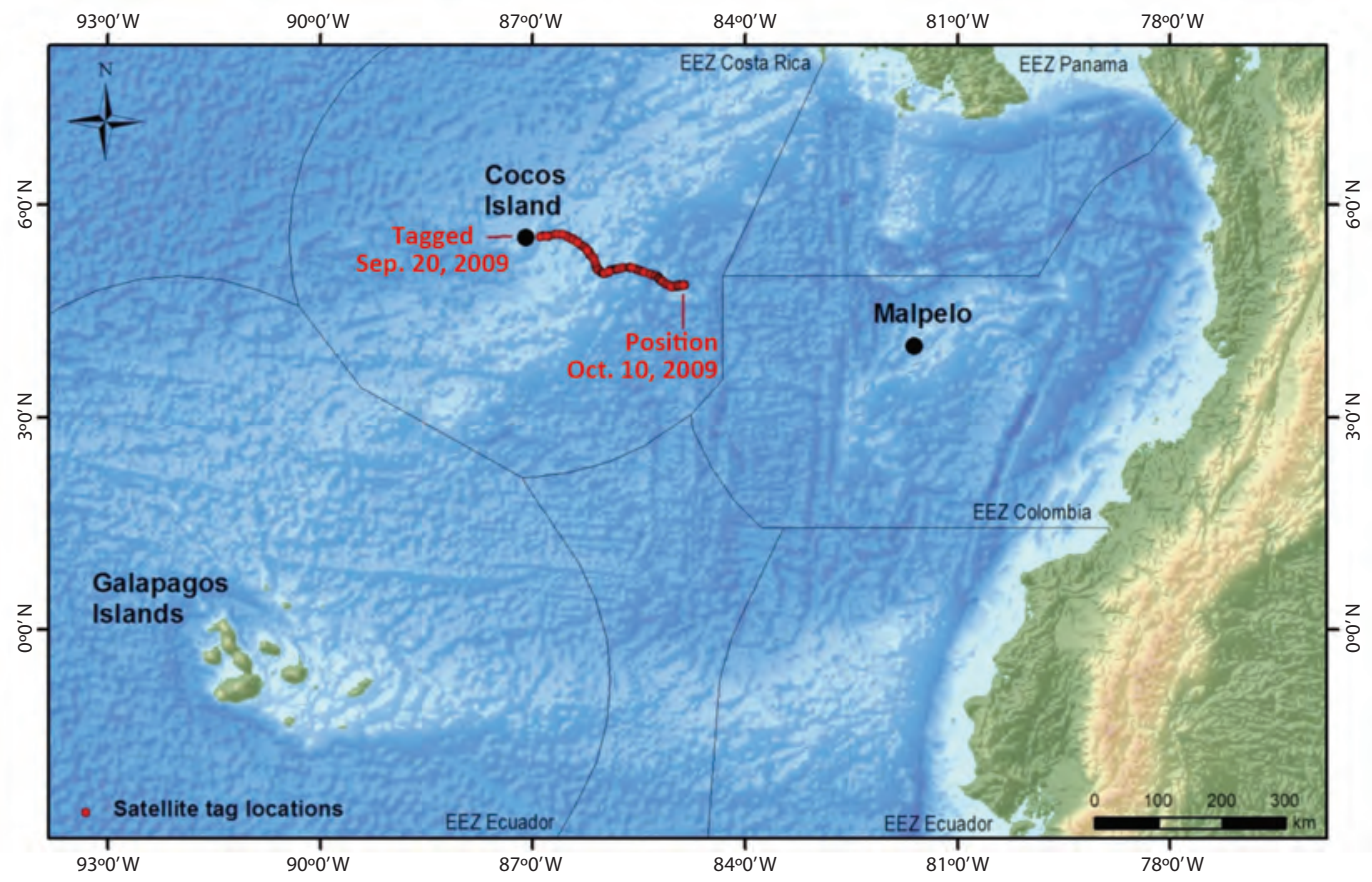

Fig. 6. Movement of one $187 \mathrm{~cm}$ TL Galapagos shark (Carcharhinus galapagensis) tagged at Isla del Coco on September 20, 2009 at ca. 6:00 with a PAT-MK3 pop-up satellite tag. On October 10, the shark had moved $255 \mathrm{~km}$ southeast of Isla del Coco, towards Malpelo Island $\left(12.8 \mathrm{~km} \mathrm{day}^{-1}\right)$.
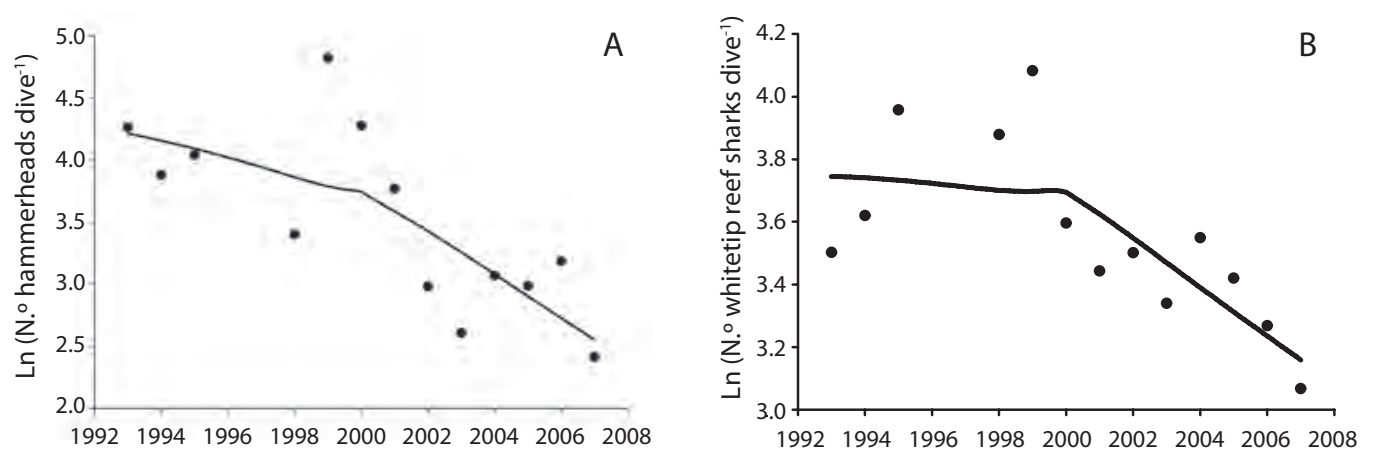

Fig. 7. (A). Number of hammerhead sharks (Sphyrna lewini) observed per dive at Isla del Coco National Park (adapted from Sibaja-Cordero 2006). (B) Number of whitetip reef sharks (Triaenodon obesus) observed per dive at Isla del Coco National Park (adapted from Sibaja-Cordero 2006). Trend lines generated using LOESS smoothing function (see text for details).

inverted biomass pyramid dominated by apex predators, primarily sharks and large schools of jacks. Planktivores also contributed greatly to the overall fish biomass, which likely reflects the high primarily productivity around the island (Acuña-González et al. 2008). Both apex predators and planktivores were more abundant around offshore islets and pinnacles relative to nearshore areas.

The modified SPC method developed for this study was designed to estimate the occurrence of hammerhead sharks, primarily at cleaning stations. We additionally enumerated a restricted list of resource species to improve 
the efficiency of sampling. This method resulted in at least 15 instantaneous replicates at the same sampling location and only covered $20 \mathrm{~m}$ of linear reef. While some species such as hammerhead sharks showed similar abundances between methods, two species in particular (whitetip reef sharks and bluefin trevally) showed densities nearly an order of magnitude lower on the SPCs compared with the belt transects. The lower densities on the SPCs may have resulted from the large number of replicates with zero value. When fewer replicates were includes, the densities became more similar, although still lower. The study was not designed to compare these modified SPCs with belt transects and therefore caution should be used in interpreting these results.

Although the Galapagos Islands are renowned globally for their unique marine fauna, both legal and illegal fishing has reduced the abundance of sharks and many other large charismatic species within the archipelago (Ruttenberg 2001, Sonnenholzner et al. 2009, Edgar et al. 2010). Because of its protection and isolation, Isla del Coco harbors unique assemblages of sharks and other large species that far exceed that of other locations within the region (Edgar et al. 2011). The dramatic recovery of corals at Isla del Coco following the massive 1982-83 El Niño event further highlights the resilience of intact predatordominated coral reefs to recovery from major perturbations (Guzman \& Cortés 2007).

Protected, remote locations are some of the few remaining examples of coral reefs without major anthropogenic influence. Surveys of the fishes of uninhabited, remote sites in the northwestern Hawaiian Islands and the northern Line Islands (Friedlander \& DeMartini 2002, DeMartini et al. 2008, Sandin et al. 2008, Friedlander et al. 2010) strongly support historical reports of great fish abundance and predator domination that characterized coral reefs before extensive fishing efforts occurred. In remote locations in the central Pacific, biomass estimates ranging from 2.5 to $5.3 \mathrm{tha}^{-1}$ have been recorded with the percentage of apex predators accounting for up to $85 \%$ of the total biomass (Sandin et al. 2008, Williams et al. 2011). Fish standing stock from various coral reef habitats on the Great Barrier Reef range from 0.9 to $2.6 \mathrm{t} \mathrm{ha}^{-1}$ (Williams \& Hatcher 1983, Arias- González et al. 2006) while remote locations from New Caledonia have recorded biomass up to $3.4 \mathrm{tha}^{-1}$ (Letourneur et al. 2000). Reef fish biomass in the remote Chagos Archipelago in the Indian Ocean dwarfs that of the rest of the western Indian Ocean (WIO), with mean biomass estimates over six times higher than the highest recorded in no-take marine protected areas in the rest of the WIO (N. Graham, unpub. data.). Remote, uninhabited locations represent some of the last remaining 'pristine' coral reefs left on earth and give us a window into the past as to what reefs looked like prior to human extraction (Knowlton \& Jackson 2008).

Shark fishing: Isla del Coco National Park harbors one of the most extraordinary predator populations in the world's oceans, which demonstrates that protection has been effective. However, this richness is at risk because of heavy shark fishing in the region, and illegal fishing inside the park. This may be due to several reasons: a) these animals follow population fluctuations over decades and they are now on a natural decline, $b$ ) increasing fishing (legal and illegal, both inside and outside the park) is depleting shark populations, or c) a combination of both.

There are indeed changes in shark abundance in the ETP caused by climate variability. During the warm, nutrient-poor El Niño years, the number of hammerhead sharks visiting Isla del Coco declines dramatically, while their abundance increases during the cold, nutrientrich La Niña years (Sibaja-Cordero 2008). However, there is no evidence in the scientific literature of shark declines taking place on a decadal scale due to environmental variability. Yet, there are many studies showing the steady decline of sharks as a result of increasing fisheries exploitation in the Atlantic (Baum et al. 2003), the Mediterranean (Ferretti et al. 2008), 
the Indian Ocean (Graham et al. 2010), and Australia (Robbins et al. 2006).

Data collected by MarViva strongly indicates that illegal fishing in the park has been occurring for years. According to MarViva's statistics, between 2004 and 2009, 1512km of illegal longlines, 48,552 hooks, and 459 hooked sharks were found inside the park. Whitetip reef shark abundances are not known to be correlated with ENSO events and illegal fishing inside the park has been known to capture these sharks in the past (MarViva, unpub. data). Therefore, we believe that fishing is the major threat to all shark populations at Isla del Coco National Park.

Fishing at or near Isla del Coco is probably not the only cause of decline of large migratory animals. Shark fishing throughout the ETP is also a major threat. Sharks are overfished in the Pacific waters of Costa Rica (Arauz et al. 2004, Espinoza 2006) and they are elsewhere around the world (Baum et al, 2003, Myers et al., 2007). Although shark and ray fisheries in Costa Rica peaked in 1999, and have been in decline since (FAO STAT 2006), even modest levels of fisheries exploitation can have detrimental effects on predatory species including sharks (Pauly et al. 1998).

Large marine predators such as sharks that spend part of the year at Isla del Coco are especially vulnerable to fishing when they migrate through the large unprotected areas between the marine parks of Coco, Malpelo, and Galapagos. Shark tagging studies and the shark tagged during our expedition, suggest the existence of migratory corridors between the oceanic ETP islands (Migramar 2009, Bessudo et al. 2011). Similar to leatherback turtles (Schillinger et al. 2008), sharks swim along routes that follow the underwater Coco Volcanic Cordillera, which extends between Costa Rica, Isla del Coco, and the Galapagos Islands. Another migratory route for sharks, which does not follow the ridge, is almost a direct line between Isla del Coco and Malpelo.

Implications for conservation: Based upon large-scale movement patterns from this and other studies, current protection of the 12 nautical miles $(22 \mathrm{~km})$ around the island is essential but insufficient to preserve the populations of these large migratory animals, especially hammerhead sharks. An expansion of the Isla del Coco National Park and effective shark fishing regulations would address some of this issue, especially if the latter were to be expanded to the surrounding waters of the ETP.

Costa Rica has protected over $25 \%$ of its land, but less than $1 \%$ of its marine waters (Alvarado et al. 2012). Measures used to conserve and protect the terrestrial resources of Costa Rica have proven to be effective. These same measures can be applied to protect the marine resources surrounding Isla del Coco starting with expanding protection of the Isla del Coco National Park that includes seamounts, to ensure the long-term preservation of one of the most extraordinary marine ecosystems on the planet. The creation of the new Seamounts Marine Management Area in March 2011 encompassing 10,000 $\mathrm{km}^{2}$ around Isla del Coco including Las Gemelas Seamount may contribute to fill this gap, and preserve an ecosystem of unique global value. However, a management plan for this new area has not been developed yet, and it is uncertain what proportion will be a no-take reserve.

Conserving marine ecosystems provides more economic revenue in the long-term than unsustainable fishing practices. In the Great Barrier Reef of Australia, for example, full protection of $30 \%$ of the Marine Park resulted in economic benefits that outweighed the costs of loss of fishing revenue, and the current value of tourism is 36 times that of fishing (McCook et al. 2010). Despite its major ecological impact, shark and ray fisheries in 2006 accounted for only $\$ 236,000$ (equivalent to $1.2 \%$ of the total value of Costa Rica fisheries: real 2000 value estimated as ex-vessel price of the catch; FAOSTAT 2006, Sea Around Us Project 2011). In contrast, tourism - most of which is ecotourism on protected land habitats - brings to Costa Rica \$2.2 billion annually.

There are five diving liveaboards that operate regularly at Isla del Coco National 
Park. At full occupancy they bring over $\$ 7$ million to the local economy (including price of the diving trip, entrance fees, Costa Rica "green tax", food and lodging). More than $85 \%$ of the divers go to Isla del Coco to observe the large predators, especially the schools of hammerhead sharks (A. Klapfer, pers. comm.). The three most popular hammerhead sites that most divers visit (Alcyone, Manuelita, and Roca Sucia) have average abundances of 42, 21 and 10 hammerheads $\mathrm{ha}^{-1}$; that is, divers see an average of 71 hammerheads sharks per diving trip. Therefore every "average" shark brings over \$82,000 to Costa Rica every year. Assuming every hammerhead (which can live to 35 years) visits Isla del Coco for 20 years; every shark would bring \$1.6 million to Costa Rica over its lifetime - and many jobs. In contrast, the average hammerhead shark caught in Costa Rican waters is bought from the fishermen at the Puntarenas fish market for only \$195 (R. Arauz, pers. comm.). Costa Rica can apply the success stories of their protection of the land to their marine waters. One approach would be to consider no take areas-perhaps the new Seamounts Marine Area in its totality - as part of the management prescription. Such actions would do much to ensure the long-term preservation of the Isla del Coco National Park, one of the most extraordinary marine ecosystems in the planet.

\section{ACKNOWLEDGMENTS}

This expedition was made possible by a research permit from the Área de Conservación Marina Isla del Coco (ACMIC). We are especially grateful to Fernando Quirós, Director of ACMIC, for the research permit that allowed us to conduct the expedition; to Geiner Golfín and his staff at Isla del Coco, and the MarViva field staff for their support in the field; and to Jenny Ash and the personnel at ACMIC and Sistema Nacional de Áreas Protegidas (SINAC) for their help and support. Special thanks to Randall Arauz, Jorge Cortés, Jorge Jiménez, Avi Klapfer, Sandra Ramírez, Michael Rothschild, Manuel Ramírez, Fabián
Sánchez, Carla Sarquis, Carlos Uribe, and our friends and colleagues at MarViva, Conservation International, The Nature Conservancy, Preservación de Tortugas Marinas, Fundación Amigos Isla del Coco, Centro de Investigación en Ciencias del Mar y Limnología (CIMAR) of the Universidad de Costa Rica, and the Undersea Hunter Group, whose enthusiastic help made this expedition possible. Huge thanks to the crews of the Hanse Explorer and the Argo, who were dedicated and tireless in their efforts to make the expedition a success. The expedition was supported by Google, National Geographic Society, Walton Family Foundation, The Campbell Foundation, Waitt Family Foundation, and private donors. The use of trade names or products does not constitute endorsement by the U.S. Government. This study was performed under the auspices of University of Hawaii Animal Care and Use Protocol 11-1284.

\section{RESUMEN}

La biomasa promedio de peces costeros en el Parque Nacional Isla del Coco en septiembre de 2010 fue de 7,8 toneladas por hectárea, entre las más elevadas halladas jamás en zonas tropicales. Los grandes depredadores representaron el $40 \%$ de la biomasa total. La abundancia de tiburones costeros y pelágicos, particularmente las enormes agregaciones de tiburón martillo (hasta 42 individuos por hectárea) y los extensos bancos de carángidos y lutjánidos, muestran la capacidad que tienen los ecosistemas marinos no pescados para albergar elevadas biomasas de peces, y hacen de la Isla del Coco un lugar único en el mundo. No obstante, la abundancia de tiburones parece estar decreciendo desde 1999, probablemente a causa de la creciente presión pesquera en la región y la pesca ilegal en el interior del Parque. Un tiburón de Galápagos marcado se dirigió $255 \mathrm{~km}$ en dirección a la Isla de Malpelo, Colombia. Estos resultados sugieren que los tiburones realizan importantes movimientos entre áreas marinas protegidas (Isla del Coco, Malpelo, Galápagos) en el Pacífico Tropical Oriental y remarcan la necesidad de una gestión regional de estos animales. Más del $50 \%$ de las especies y el $90 \%$ de individuos observados en los contajes eran endémicos del Pacífico Tropical Oriental.

Palabras clave: grandes depredadores, Pacífico tropical oriental, isla del Coco, pesca de tiburones, áreas marinas protegidas, endemismos, sitios de alta biodiversidad, Costa Rica. 


\section{REFERENCES}

Acuña-González, J. A., J. García-Céspedes, E. GómezRamírez, J. A. Vargas-Zamora \& J. Cortés. 2008. Parámetros físico-químicos en aguas costeras de la Isla del Coco, Costa Rica (2001-2007). Rev. Biol. Trop. 56 (Suppl. 2): 49-56.

Alvarado, J.J., J. Cortés, M.F. Esquivel \& E. Salas. 2012. Costa Rica's marine protected areas: review and perspectives. Rev. Biol. Trop. 60: 129-142

Alfaro, E.J. 2008. Ciclo diario y annual de variables troposféricas y oceánicas en la Isla del Coco, Costa Rica. Rev. Biol. Trop. 56 (Suppl. 2): 19-29.

Arauz, R., Y. Cohen, J. Ballestero, A. Bolaños \& M. Pérez. 2004. Decline of shark populations in the Exclusive Economic Zone of Costa Rica. International Symposium on Marine Biological Indicators for Fisheries Management. UNESCO, FAO, Paris, France.

Arias-González J.E., T.J. Done, C.A. Page, A. J. Cheal, S. Kininmonth, J. R. Garza-Pérez. 2006. Towards a reefscape ecology: relating biomass and trophic structure of fish assemblages to habitat at Davies Reef, Australia. Mar. Ecol. Prog. Ser. 320: 29-41

Bakus, G.J. 1975. Marine zonation and ecology of Cocos Island, off central America. Atoll Res. Bull. 179: $1-11$.

Baum, J., R. Myers, D.G. Kehler, B. Worm, S.J. Harley \& P.A. Doherty. 2003. Collapse and conservation of shark populations in the Northwest Atlantic. Science 299: 389-392.

Bessudo, S., G.A. Soler, A. P. Klimley, J.T., Ketchum, A. Hearn, R. Arauz. 2011. Residency of the scalloped hammerhead shark (Sphyrna lewini) at Malpelo Island and evidence of migration to other islands in the Eastern Tropical Pacific. Environ. Biol. Fish. 91:165-176

Bussing, W.A. \& M.I. López. 2005. Peces de la Isla del Coco y peces arrecifales de la costa Pacífica de América Central meridional/Fishes of Cocos Island and Reef Fishes of the Pacific Coast of Lower Central America. Rev. Biol. Trop. 53 (Supl. 2): 192 p.

Castillo, R., R. Batista, D. Vanco, E. Malavassi, J. Barquero \& E. Fernández. 1988. Anomalously young volcanoes on hot spot traces: I. Geology and petrology of Cocos Island. Geol. Soc. Amer. Bull. 100: $1400-1414$.

Clarke, K., R. Gorley. 2001. PRIMER v5: User manual/ tutorial. Primer-E Ltd., Plymouth, UK

Clarke, K., R. Warwick. 2001. Change in marine communities: an approach to statistical analysis and interpretation. 2nd edition, Primer-E Ltd., Plymouth, UK

Cortés, J. 2008. Historia de la investigación marina de la Isla del Coco, Costa Rica. Rev. Biol. Trop. 56 (Suppl. 2): $1-18$.
DeMartini, E.E., A.M. Friedlander, S.A. Sandin \& E. Sala. 2008. Differences in fish assemblage structure between fished and unfished atolls in the northern Line Islands, central Pacific. Mar. Ecol. Prog. Ser. 365: 199-215.

Edgar, G.J., S.A. Banks, M. Brandt, R.H. Bustamante, A. Chiriboga, S.A. Earle, L.E. Garske, P.W. Glynn, J.S. Grove, S. Henderson, C.P. Hickman, K.A. Miller, F. Rivera \& G. Wellington. 2010. El Niño, fisheries and animal grazers interact to magnify extinction risk for marine species in Galapagos. Global Change Biol. 16: 2876-2890.

Edgar, G.J., S.A. Banks, S. Bessudo, J. Cortés, H.M. Guzman, S. Henderson, C. Martínez, F. Rivera, G. Soler, D. Ruiz \& F. Zapata. 2011. Variation in reef fish and invertebrate communities with level of protection from fishing across the Eastern Tropical Pacific seascape. Global Ecol. Biogeogr. 20: 730-743.

Espinoza, M. 2006. Tiburones, p. 119-134. In V. Nielsen \& M.A. Quesada (eds.). Ambientes marino costeros de Costa Rica. Comisión Interdisciplinaria Marino Costera de la Zona Económica Exclusiva de Costa Rica. Informe Técnico.

Estes, J.A., J. Terborgh, J.S. Brashares, M.E. Power, J. Berger, W.J. Bond, S.R. Carpenter, T.E. Essington, R.D. Holt, J.B.C. Jackson, R.J. Marquis, L. Oksanen, T. Oksanen, R.T. Paine, E.K. Pikitch, W.J. Ripple, S.A. Sandin, M. Scheffer, T.W. Schoener, J.B. Shurin, A.R.E. Sinclair, M.E. Soulé, R. Virtanen \& D.A. Wardle. 2011. Trophic downgrading of planet Earth. Science 333: 301-306.

Ferretti, F., R.A. Myers, F. Serena \& H.K. Lotze. 2008. Loss of large predatory sharks from the Mediterranean Sea. Conserv. Biol. 22: 952-964.

Friedlander, A.M. \& E.E. DeMartini. 2002. Contrasts in density, size, and biomass of reef fishes between the Northwestern and the main Hawaiian Islands: the effects of fishing down apex predators. Mar. Ecol. Prog. Ser. 230: 253-264.

Friedlander A.M., E.K. Brown, P.L. Jokiel. W.R. Smith, \& K.S. Rodgers. 2003. Effects of habitat, wave exposure, and marine protected area status on coral reef fish assemblages in the Hawaiian archipelago. Coral Reefs 22: 291-305.

Friedlander, A.M., S.A. Sandin, E.E. DeMartini \& E. Sala. 2010. Habitat-specific characterization of the fish assemblage at a piscivore-dominated, pristine atoll in the central Pacific. Mar. Ecol. Prog. Ser. 410: 219-231.

Garrison, G. 2005. Peces de la Isla del Coco, 2nd edn. Edit. INBio, Heredia, Costa Rica

Graham, N.A.J., M.D. Spalding \& C.R.C. Sheppard. 2010. Reef shark declines in remote atolls highlight the need for multi-faceted conservation action. Aquat. Conserv. Mar. Freshw. Ecosyst. 20: 543-548. 
Guzman, H.M. \& J. Cortés. 2007. Reef recovery 20-yr after the 1992-83 El Niño massive mortality. Mar. Biol. 151: 401-411.

Halpern, B.S., S. Walbridge, K.A. Selkoe, F. Micheli, C. D’Agrosa \& others. 2008. A global map of human impact on marine ecosystems. Science 319: 948-952.

Hastings, P.A. 2000. Biogeography of the Tropical Eastern Pacific: distribution and phylogeny of chaenopsid fishes. Zool. J. Linnean Soc. 128: 319-335.

Hastings, P.A. \& D.R. Robertson. 2001. Systematics of tropical eastern Pacific fishes. Rev. Biol. Trop. 49 (Suppl. 1): 12-14.

Jackson, J.B.C., M.X. Kirby, W.H. Berger, K.A. Bjorndal \& others. 2001. Historical overfishing and the recent collapse of coastal ecosystems. Science 293: 629-638.

Knowlton, N. \& J.B.C. Jackson. 2008. Shifting baselines, local impacts, and global change on coral reefs. PLoS Biol. 6:e54. doi:10.1371/journal.pbio.0060054.

Kulbicki, M., N. Guillemot \& M. Amand. 2005. A general approach to length-weight relationships for New Caledonian lagoon fishes. Cybium 29:235-252.

Letourneur, Y. 1998. Length-weight relationship of some marine fish species in Reunion Island, New Caledonia. Naga ICLARM Q 21:39-46.

Mapstone, B.D. \& A.M. Ayling. 1998. An Investigation of the Optimum Methods and Unit Sizes or the Visual Estimation of Abundance of Some Coral Reef Organisms. Great Barrier Reef Mar. Park Auth. Res. Publ. No. 47, Townsville, QLD.

McCook, L.J., T. Ayling, M. Cappo, J.H. Choat, R.D. Evans, D.M. DeFreitas, M. Heupel, T.P. Hughes, G.P. Jones, B. Mapstone, H. March, M. Mills, F.J. Molloy, C.R. Pitcher, R.L. Pressey, G.R. Russ, S. Sutton, H. Sweatman, R. Tobin, D.R. Wachenfeld, \& D.H. Williamson. 2010. Adaptive management of the Great Barrier Reef: A globally significant demonstration of the benefits of networks of marine reserves. Proc. Natl. Acad. Sci. U.S.A. 107: 18278-18285.

Mora, C., O. Aburto-Oropeza, A. Ayala Bocos, P.M. Ayotte, S. Banks, A.G. Bauman, M. Beger, S. Bessudo, D.J. Booth, E. Brokovich, A. Brooks, P. Chabanet, J. Cinner, J. Cortés, J.J. Cruz-Motta, A. Cupul Magaña, E. DeMartini, G.J. Edgar, D.A. Feary, S.C.A. Ferse, A. Friedlander, K.J. Gaston, C. Gough, N.A.J. Graham, A. Green, H. Guzman, M. Hardt, M. Kulbicki, Y. Letourneur, A. López Pérez, M. Loreau, Y. Loya, C. Martinez, I. Mascareñas-Osorio, T. Morove, M-O. Nadon, Y. Nakamura, G. Paredes, N. Polunin, M.S. Pratchett, H. Reyes Bonilla, F. Rivera, E. Sala, S. Sandin, G. Soler, R. Stuart-Smith, E. Tessier, D.P. Tittensor, M. Tupper, P. Usseglio, L. Vigliola, L. Wantiez, I. Williams, S.K. Wilson, F.A. Zapata. 2011. Global human footprint on the linkage between biodiversity and ecosystem functioning in reef fishes. PLoS Biol 9(4): e1000606. doi:10.1371/ journal.pbio.1000606.

Myers, R.A., J.K. Baum, T.D. Shepherd, S.P. Powers \& C.H. Peterson. 2007. Cascading effects of the loss of apex predatory sharks from a coastal ocean. Science 315: 1846-1850.

Pauly, D., V. Christensen, J. Dalsgaard, R. Froese \& F. Torres. 1998. Fishing down marine food webs. Science 279: $860-863$.

Robbins, W., M. Hisano, S.R. Connolly \& J.H. Choat. 2006. Ongoing collapse of coral reef shark populations. Curr. Biol. 16: 2314-2319.

Roberston, D.R. \& K.L. Cramer. 2009. Shore fishes and biogeographic subdivisions of the Tropical Eastern Pacific. Mar. Ecol. Prog. Ser. 380: 1-17.

Robertson, R.D., J.S. Grove, J.E. McCosker. 2004. Tropical transpacific shore fishes. Pac. Sci. 58: 507-565.

Ruttenberg. B.I. 2001. Effects of artisanal fishing on marine communities in the Galapagos Islands. Conserv. Biol. 15: 1691-1699.

Sandin, S.A., J.E. Smith, E.E. DeMartini, E.A. Dinsdale, S.D. Donner, A.M. Friedlander, T. Konotchick, M. Malay, J.E. Maragos, D. Obura, O. Pantos, G. Paulay, M. Richie, F. Rohwer, R.E. Schroeder, S. Walsh, J.B.C. Jackson, N. Knowlton \& E. Sala. 2008. Degradation of coral reef communities across a gradient of human disturbance. PLoS ONE. 2008; 3(2):e1548

Shillinger, G.L., D.M. Palacios, H.R. Bailey, S.J. Bograd, A. Swithenbank, P. Gaspar, B. Wallace, J.R. Spotila, F.V. Paladino, R. Piedra, S.A. Eckert, and B.A. Block. 2008. Persistent Leatherback Turtle migrations present opportunities for conservation. PLoS Biol. 6(7): e171. doi:10.1371/journal.pbio.0060171

Sibaja-Cordero, J.A. 2008. Tendencias espacio-temporales de los avistamientos de fauna marina en los buceos turísticos (Isla del Coco, Costa Rica). Rev. Biol. Trop. 56 (Suppl. 2): 113-132.

Sonnenholzner, J.I., L.B. Ladah, K.D. Lafferty. 2009. Cascading effects of fishing on Galapagos rocky reef communities: reanalysis using corrected data. Mar. Ecol. Prog. Ser. 375: 209-218.

Starr, R.M., K. Green \& E. Sala. 2012. Deepwater fish assembles at Isla del Coco National Park and Las Gemelas Seamonts, Costa Rica. Rev. Biol. Trop. 60 (Suppl. 3): 347-362.

Thresher, R.E.\& J.S. Gunn. 1986, Comparative analysis of visual census techniques for highly mobile, reefassociated piscivores (Carangidae). Environ. Biol. Fish. 17: 93-116.

Williams, I.D., B.L. Richards, S.A. Sandin, J.K. Baum, R.E. Schroeder, M.O. Nadon, B. Zgliczynski, P. Craig, J.L. McIlwain, R.E. Brainard. 2011. Differences in reef fish assemblages between populated and remote reefs spanning multiple archipelagos 
across the central and western Pacific. J. Marine Biology Volume 2011, Article ID 826234, 14 pages doi:10.1155/2011/826234

Zar, J.H. 1999. Biostatistical Analysis, 4th edn. Prentice Hall,Upper Saddle River, New Jersey.

\section{Internet references}

FAO. 2006. The State of World Fisheries and Aquaculture. FAO Fisheries and Aquaculture Department, Rome. http://www.fao.org/docrep/009/a0699e/A0699E00. htm

Froese, R. \& D. Pauly. Editors. 2011.FishBase.World Wide Web electronic publication. version (12/2011). Downloaded November 15, 2011. www.fishbase.org.
Migramar. 2009. Estudio sobre residencia y hábitos migratorios de tiburones del Parque Nacional Isla del Coco, 28 p. http://www.migramar.org/results.html

Robertson, D.R. \& G.R. Allen. 2008. Shorefishes of the Tropical Eastern Pacific online information system. Version 1.0 (2008). Smithsonian Tropical Research Institute, Balboa, Panamá. Downloaded February 10, 2010. www.neotropicalfishes.org/sftep, www. stri.org/sftep

Sea Around Us Project. 2011. Electronic Publication. Fisheries Research Center, University of British Columbia. http://www.seaaroundus.org/eez/188/12.aspx 